\title{
Peran dan Strategi Nahdlatul Ulama sebagai organisasi masyarakat di Indonesia
}

\section{The Role and Strategy of Nahdlatul Ulama as a Community Organization in Indonesia}

\author{
Oma Irama \\ Kementerian Agama Sulawesi Tenggara \\ E-mail: Iramaoma72@gmail.com \\ La Sensu \\ Pascasarjana Universitas Halu Oleo \\ E-mail: lalensu18gmail.com \\ Guasman Tatawu \\ Pascasarjana Universitas Halu Oleo \\ E-mail: gtatawu@gmail.com
}

\begin{abstract}
The purpose of this study is to find out and analyze the role and strategy of Nahdlatul Ulama as a community organization in the legal paradigm in Indonesia and to find out and analyze whether Nahdlatul Ulama's policy as an independent organization in a pluralistic Indonesian society. This research method is a method with a normative juridical approach or doctrinal legal research. In normative legal research, only library materials or secondary data are examined, which may include primary, secondary and tertiary legal materials. The conclusion of this research is Nahdlatul Ulama led by Hadhratus Shaykh KH. Hasyim Asy'ari highly upholds national values, nationalism based on Islamic law in the style of Ahl al-Sunnah wal-Jamä'ah. The proof of the nationalist attitude shown by Nahdlatul Ulama' is the incident where before the independence of the Republic of Indonesia, youths in various regions established regional organizations, such as Jong Cilebes, Betawi Youth, Jong Java, Jong Ambon, Jong Sumatra, and so on. Kyai NU instead founded a youth organization that is nationalist.
\end{abstract}

Keyword: Nahdlatul Ulama; Independent; Legal

Abstrak: Tujuan Penelitian ini adalah Untuk mengetahui dan menganalisis Apa peran dan strategi Nahdlatul Ulama sebagai organisasi masyarakat dalam paradigma hukum di Indonesia dan Untuk mengetahui dan menganalisis apakah Kebijakan Nahdlatul Ulama sebagai organisasi independen dalam masyarakat Indonesia yang pluralisme. Metode Penelitian ini adalah metode dengan pendekatan Yuridis normatif atau penelitian hukum doktrinal. Pada penelitian hukum normatif, yang diteliti hanya bahan pustaka atau data sekunder, yang mungkin mencakup bahan hukum primer, sekunder dan tertier. Kesimpulan penelitian ini adalah Nahdlatul Ulama pimpinan Hadhratus Syaikh KH. 
Hasyim Asy'ari sangat menjunjung tinggi nilai-nilai kebangsaan, nasionalisme yang berdasar atas syariat Islam ala Ahl al-Sunnah wal-Jamā'ah. Bukti sikap nasionalis yang tunjukkan Nahdlatul Ulama' adalah peristiwa dimana sebelum negara Republik Indonesia merdeka, para pemuda di berbagai daerah mendirikan organisasi bersifat kedaerahan, seperti Jong Cilebes, Pemuda Betawi, Jong Java, Jong Ambon, Jong Sumatera, dan sebagainya, akan tetapi Kyai-Kyai NU justru mendirikan organisasi pemuda bersifat nasionalis.

Kata kunci: Nahdlatul Ulama; Independen; Hukum

\section{PENDAHULUAN}

Negara Republik Indonesia sebagai negara hukum artinya hukum menjadi pedoman atau landasan oleh Pemerintah dalam menjalankan Pemerintahan Negara. Selain itu, UUD RI tahun 1945 juga mengatur bahwa Negara Indonesia adalah Negara Kesatuan yang berbentuk republik, dan dalam kaitan dengan susunan negara, disebut negara kesatuan, sehingga di dalam negara tidak ada kesatuan masyarakat daerah yang boleh merupakan suatu negara1.

Makna negara hukum menurut pembukaan UUD 1945 tidak lain adalah negara hukum dalam arti materiil, yaitu negara yang melindungi segenap bangsa Indonesia seluruhnya, tumpah darah Indonesia dan untuk memajukan kesejahteraan umum, mencerdaskan kehidupan bangsa dan ikut serta dalam menjaga perdamaian dunia berdasarkan kemerdekaan, perdamaian abadi dan keadilan sosial, yang di susun dalam suatu UUD RI tahun 1945 yang berdasarkan Pancasila².

Negara Indonesia memiliki salah satu prinsip dasar yang ditegaskan dalam perubahan UUD 1945 yaitu prinsip negara hukum, sebagaimana tertuang dalam Pasal 1 ayat (3) UUD 1945 yang menyatakan bahwa 'Negara Indonesia adalah negara hukum'3. Bahkan secara historis negara hukum (rechtsstaat) adalah negara yang diidealkan oleh para pendiri bangsa sebagaimana dituangkan dalam penjelasan umum UUD 1945 sebelum perubahan tentang sistem pemerintahan negara yang menyatakan bahwa Negara Indonesia berdasar atas hukum (rechtsstaat), tidak berdasarkan kekuasaan belaka (machtsstaat).

Peraturan Pemerintah Pengganti Undang-Undang Republik Indonesia Nomor 2 Tahun 2017 Tentang Organisasi kemasyarakatan pada pasal 1 dalam Undang-Undang ini yang

1 Achmad Ruslan, Teori dan panduan Praktik Pembentukan Peraturan Perundang-undangan di Indonesia, Yogyakarta: Rangkang Education dan Republik Institute, 2013, hlm, 3.

2 Ibid.

3 Pasal 1 ayat (3) Undang-Undang Dasar 1945 Hasil Amandemen. Redaksi Sinar Grafika, Undang-Undang 1945 Hasil Amandemen dan Proses Amandemen Undang-Undang 1945 Secara Lengkap, cetakan keenam, Jakarta: Sinar Grafika, 2009, hlm, 4. 
dimaksud dengan Organisasi kemasyarakatan yang selanjutnya disebut Ormas adalah organisasi yang didirikan dan dibentuk oleh masyarakat secara sukarela berdasarkan kesamaan aspirasi, kehendak, kebutuhan, kepentingan, kegiatan dan tujuan untuk berpartisipasi dalam pembangunan demi tercapainya tujuan Negara Kesatuan Republik Indonesia yang berdasarkan Pancasila dan Undang-Undang Dasar Negara Republik Indonesia Tahun 1945.

Kedudukan sebagai organisasi masyarakat, Nahdlatul Ulama tentunya menjadi mitra sebuah bangsa Indonesia dalam menyelenggarakan sistem ketatanegaraan yang baik dan bersih dan mengawasi segala bentuk kebijakan yang dibuat dan dijalankan oleh sebuah lembaga Negara. Organisasi tersebut menjalankan perannya sesuai dengan ajaran Islam dalam hal ini fiqhsiyasah karena sebagai organisasi masyarakat, Nahdlatul Ulama mengajarkan musyawarah sebagai media pengambilan keputusan bersama selain itu ajaran tentang keadilan yang harus ditegakkan tanpa memandang status sosial dan latar belakang seseorang.

Nahdlatul Ulama merupakan ormas Islam terbesar di Indonesia. Potensi yang besar ini jika dimanfaatkan dengan maksimal bisa memberikan efek positif dalam pembangunan Indonesia. Peranan yang sangat urgen ini telah dipikul dan laksanakan oleh ormas Nahdlatul Ulama selama puluhan tahun semenjak organisasi ini didirikan oleh Kyai Hasyim Asy'ari. Berdirinya Nahdlatul Ulama diprakarsai oleh lima belas kiai terkemuka, mereka berkumpul di rumah K.H. Wahab Hasbullah di Kertopaten Surabaya, sebagian besar mereka datang dari Jawa Timur dan masing-masing adalah tokoh pesantren.

Nahdlatul Ulama didirikan oleh sejumlah tokoh ulama tradisional dan usahawan Jawa Timur, pembentukannya sebagai reaksi satu sisi terhadap berbagai aktivitas kelompok Reformis, Muhammadiyah dan kelompok modernis moderat yang aktif dalam gerakan politik, Sarekat Islam, sisi lain terhadap perkembangan politik dan paham keagamaan tingkat internasional, oleh karenanya ada tiga penyebab lahirnya Nahdlatul Ulama, yaitu (1) gerakan pembaharu di Indonesia (2) kepentingan Politik atau (3) perkembangan timur tengah. ${ }^{4}$

Adapun dari segi religius dan spiritualitas, proses berdirinya Nahdlatul Ulama melalui istikharah dan permohonan kepada Allah. K.H. As'ad Syamsul Arifin yang mempunyai peran penting sebagai mediator dari dimensi spiritual dan proses berdirinya Nahdlatul Ulama. Beliau menggambarkan betapa beratnya mendirikan jamiyyah ulama, hingga K.H Kholil Bangkalan

4 Sudarno Shobron, Muhammadiyah dan NU Dalam Pentas Politik Nasional. Surakarta : Muhammadiyah University Press, 2009, hlm. 37-38, 
perlu dua kali mengutus dirinya pergi ke Tebuireng Jombang untuk menyampaikan sesuatu kepada K.H. Hasyim Asy’ari.

Berdirinya Nahdlatul Ulama tidak melalui Proses administratif melainkan melalui permohonan kepada Allah. Ketika itu K.H. Wahab memberikan usulan kepada K.H. Hasyim untuk membentukjam'iyah para ulama, K.H. Hasyim As'ari minta petunjuk kepada Allah, namun petunjuk tersebut tak kunjung tiba, akan tetapi petunjuk itu malah datangnya dari sang guru K.H. Kholil Bangkalan. K.H. As'ad berperan sebagai mediator untuk mengantarkan Isyarah dari K.H Kholil kepada K.H. Hasyim Asy’ari.

Adapun dari segi religius dan spiritualitas, proses berdirinya Nahdlatul Ulama melalui istikharah dan permohonan kepada Allah. K.H. As'ad Syamsul Arifin yang mempunyai peran penting sebagai mediator dari dimensi spiritual dan proses berdirinya Nahdlatul Ulama. Beliau menggambarkan betapa beratnya mendirikan jamiyyah ulama, hingga K.H Kholil Bangkalan perlu dua kali mengutus dirinya pergi ke Tebuireng Jombang untuk menyampaikan sesuatu kepada K.H. Hasyim Asy’ari.

Berdirinya Nahdlatul Ulama tidak melalui Proses administratif melainkan melalui permohonan kepada Allah. Ketika itu K.H. Wahab memberikan usulan kepada K.H. Hasyim untuk membentukjam'iyah para ulama, K.H. Hasyim As'ari minta petunjuk kepada Allah, namun petunjuk tersebut tak kunjung tiba, akan tetapi petunjuk itu malah datangnya dari sang guru K.H. Kholil Bangkalan. K.H. As'ad berperan sebagai mediator untuk mengantarkan Isyarah dari K.H Kholil kepada K.H. Hasyim Asy’ari.

Berdasarkan dari uraian di atas, maka peneliti merasa tertarik untuk melakukan suatu penelitian dengan judul "Peran dan Strategi Nahdlatul Ulama sebagai organisasi masyarakat di Indonesia" Untuk itu latar belakang sebagaimana diuraikan di atas, maka secara konkret, Rumusan masalah penelitian ini dapat rumuskan sebagai berikut: Apa peran dan strategi Nahdlatul Ulama sebagai organisasi masyarakat dalam paradigma hukum di Indonesia? Dan Apa Kebijakan Nahdlatul Ulama sebagai organisasi independen dalam masyarakat Indonesia yang pluralisme.

\section{METODE PENELITIAN}

Metode penelitian yang digunakan dalam penelitian ini adalah metode dengan pendekatan Yuridis normatif atau penelitian hukum doktrinal. Pada penelitian hukum normatif, yang diteliti hanya bahan pustaka atau data sekunder, yang mungkin mencakup bahan hukum primer, 
sekunder dan tertier. ${ }^{5}$ Dalam penelitian hukum yang normatif yang disebut juga penelitian hukum yang doktrinal biasanya hanya digunakan sumber-sumber data sekunder saja yaitu peraturan-peraturan perundang-undangan, keputusan-keputusan pengadilan, teori-teori hukum dan pendapat-pendapat para sarjana hukum terkemuka, sedangkan analisis yang dilakukan berupa analisis normatif kualitatif. ${ }^{6}$

Spesifikasi penelitian dalam tulisan ini adalah menggunakan deskriptif analitis. Hasil dari penelitian ini diharapkan akan dapat memberikan gambaran mengenai obyek yang akan diteliti. Penggambarannya berdasarkan fakta dan data mengenai kedudukan hukum Nahdlatul Ulama sebagai organisasi masyarakat di Indonesia.

Dalam penyusunan tulisan ini, penelitian yang digunakan adalah penelitian hukum normatif yang berupa pengkajian terhadap beberapa aturan-aturan hukum (peraturan perundang-undangan) sekaligus konsep dan landasan teori yang terkait dalam rangka menjawab isi dari permasalahan dan konsep yang diutarakan dalam hal kajian tentang peran dan strategi Nahdlatul Ulama sebagai organisasi masyarakat dalam masyarakat Indonesia.

\section{ANALISIS DAN PEMBAHANSAN}

\section{Peran dan Strategi Nahdlatul Ulama Sebagai Organisasi Masyarakat Dalam Paradigma}

\section{Hukum}

Berdasarkan hasil penelitian ini, sebagai organisasi keagamaan, Nahdlatul Ulama tetap memiliki keunikan untuk diamati, diteliti dan dibaca dari berbagai optik, optik politik, pemikiran, lebihlebih masalah pemahaman terhadap sumber hukum positif dan hukum Islam.

Menarik untuk dilihat kembali, berangkat dari keunikan Nahdlatul Ulama yang dalam memahami dan sekaligus pengambilan hukum (istinbat al-hukm) 'seakan-akan' tidak didasarkan pada keorisinalan pemahaman mereka terhadap kedua sumber tersebut. Maka dari itu muncul banyak pernyataan maupun kritikan bahwa organisasi yang konon terbesar di Indonesia ini dalam mengambil keputusan dan menjawab persoalan umat tidak bersumber dari al-Qur'an dan al-Hadits minimal tidak langsung bersumber dari al-Qur'an dan hadis sehingga memicu pertentangan di antara sesama umat menyangkut Amaliyah NU.

Sebagai satu jamiyah keagamaan dan organisasi kemasyarakatan, NU memiliki prinsipprinsip yang berkaitan dengan upaya memahami dan mengamalkan ajaran Islam, baik yang berhubungan dengan komunikasi vertikal dengan Allah SWT maupun komunikasi horizontal

Soerjono Soekanto, Pengantar Penelitian Hukum, Jakarta: UI Press, 1981, hlm. 52.

6 R.H Soemitro, Metodologi Penelitian Hukum, Jakarta: Ghalia Indonesia, 1983, hlm. 9. 
dengan sesama manusia. Nahdlatul Ulama' mendasarkan paham keagamaannya kepada sumber ajaran Islam, yakni al-Qur'an, al-Sunnah (hadis), al-Ijma', al-qiyas. Dalam memahami serta menafsirkan Islam dari berbagai sumber tersebut, NU mengikuti paham Ahlussunnah Wa al-Jama'ah, dengan memakai jalan pendekatan (mazhab) sebagai berikut:

a) Di bidang akidah, NU menganut paham ahlussunnah wa al-jama'ah yang dipelopori oleh oleh Imam Abu Hasan al-Asy'ari (260-324 H), dan Imam Abu Mansyur alMaturidi (w. 333 H/944 M).

b) Di bidang fikih, NU mengikuti jalan pendekatan salah satu dari empat mazhab, keempat mazhab tersebut adalah Abu Hanifah An Num'an (80-150 H/ 700-767 M), imam Malik bin Anas (93-179 H/713-795 M), Imam Muhammad bin Idris Al-Syafi'i (150-204 H/767-820 M) serta Imam Ahmad bin Hanbal (164-241 H/780-855 M).

c) Di bidang tasawuf, NU mengikuti tasawuf Imam Al-Junaidi Al-Baghdadi (w.297 H), dan Imam Abu Hamid al-Ghazali (450-505 H). ${ }^{7}$

Realitas empiris, warga NU walaupun lebih condong kepada al-Asy'ari ketimbang alMaturidi dalam bidang akidah, namun kenyataannya mereka lebih akrab dengan kitab-kitab karya al-Juwaini, al-Baqillani, al-Sanusi dan lain-lain, dibanding dengan karya-karya al-Asy'ari, apalagi al-Maturidi. Demikian juga dalam bidang fikih, walaupun mereka (nahdiyyin) lebih condong mazhab syafi'i dibanding tiga mazhab yang lainnya namun mereka hanya lebih mengenal kitab-kitab pengikut Syafi'i ketimbang karya Imam syafi'i Sendiri seperti Al-Umm.

Bidang Tasawuf meskipun lebih condong kepada al-Ghazali dan itu pun sebatas kitab Bidayah al-Hidayah dan Ihya' Ulumuddin namun mereka lebih dekat dengan Syekh Abdul Qodir Jaelani dengan Manaqibnya. Keterikatan NU dalam bidang akidah, fikih dan tasawuf dan mazhab-mazhab di atas menjadikan warga NU dikategorikan sebagai kaum Tradisionalis. Paham keagamaan yang dianut NU tersimpul dalam sebuah "kaidah"

Memelihara nilai-nilai terdahulu yang sudah baik, dan mengambil nilai-nilai baru yang lebih baik, dan "Kaidah" ini sebenarnya bukan klaim tunggal NU, dan NU juga tidak pernah mengklaim sebagai satu-satunya kaidah miliknya, yang hanya saja populer di kalangan warga NU (Nahdliyyin), 8

Landasan pijak "kaidah" di atas adalah universal, dalam arti banyak hal, peristiwa maupun ajaran yang orientasinya "memelihara yang sudah baik dan mengambil yang lebih

7 Aswaja dan Ke-NU-an, Yogyakarta: Ma'arif NU DIY, 2004, dalam "Dasar-Dasar Paham Keagamaan Nahdlatul Ulama", Laduni.id, https://www.laduni.id/post/read/61456/dasar-dasar-paham-keagamaannahdlatul-ulama, diakses pada tanggal 12 September 2021.

8 Ibid. 
baik." Ajaran Islam sendiri juga pada hakikatnya demikian. Nilai-nilai masa lalu yang baik dipertahankan dengan memperkenalkan syariat (ajaran) baru yang lebih baik, bahkan sekitar dua pertiga al-Qur'an menceritakan umat masa lalu agar umat masa kini dapat memetik hikmah dan pelajaran darinya. ${ }^{9}$

Dapat dipahami dari uraian Nurcholis Madjid, salah seorang intelektual muslim pembaru yang getol memperkenalkan "kaidah" tersebut dalam banyak tulisannya, bahwa dalam konteks keindonesiaan seharusnya "kaidah" tersebut seharusnya milik semua organisasi kemasyarakatan Islam, baik yang tradisionalis maupun modernis, baik NU, NW, Persis, Muhammadiyah, al-Irsyad ataupun lainnya tanpa perlu ada yang diperselisihkan. ${ }^{10}$ Yang perlu justru saling memahami karena masing-masing merasa ikut memiliki kaidah tersebut, namun jika harus berbagi, biarlah yang tradisionalis mengurusi sedang yang modernis agar tetap memperhatikan namun tetap dalam kesatuan "kaidah" dalam arti berbagi tugas tanpa perlu terjadi pembelahan yang menjurus kepada perpecahan. ${ }^{11}$

Bertolak dari kaidah di atas NU dengan gigih berusaha mempertahankan nilai-nilai terdahulu yang diyakini baik yang dibidang fikih terwujud dalam kesetiaan Lajnah Bahtsul Masa'il pada naskah kitab-kitab kuning sebagai andalan utama guna menghadapi berbagai masalah keagamaan yang diajukan masyarakat Nahdliyin sekalipun persoalan tersebut dapat dikategorikan sebagai maslah fikih kontemporer seperti transplantasi organ tubuh, cloning gen, demonstrasi dan sebagainya. ${ }^{12}$

Bentuk lain dari kekukuhan NU dalam mempertahankan nilai-nilai terdahulu yang diyakini baik adalah sikap toleran dan kooperatifnya terhadap tradisi keberagaman yang telah berkembang dimasyarakat, seperti membaca barzanji dan diba'an (sejarah dan pujian terhadap bagi Nabi SAW), wiridan kolektif seusai salat berjamaah, puji-pujian antara azan dan iqamat, tahlilan (membaca kalimat "thayyibah" la ilaha illallah dirangkai dengan bacaan-bacaan tertentu), yasinan (membaca surat Yasin dalam waktu-waktu tertentu), yang menurut kaum modernis tidak perlu lagi dilestarikan, bahkan sebagian menganggapnya sebagai bidah yang harus diberantas.

\footnotetext{
9 Ahmad Zahro, Tradisi Intelektual NU Lajnah Bahtsul Mas"ail 1926-1999, Yogyakarta: LKIS Yogyakarta 2004, hlm. 20, dalam Fikri Hamdani, “Wacana Hadis dalam Manhaj Nahdlatul Ulama'”, Rausyan Fikr, Vol. 13 No.1 Juni 2017, hlm. 32-33.

10 Ibid., hlm. 21-22.

11 Ibid., hlm. 22.

12 Ibid.
} 


\section{Kebijakan Nahdlatul Ulama' Sebagai Organisasi Independent Dalam Masyarakat Indonesia Yang Pluralisme}

Peneliti melakukan kajian yang mendasarkan pada konsep Nahdlatul Ulama' sebagai organisasi masyarakat dan melihat Negara Indonesia sebagai Negara bekas jajahan Belanda. Maka Belanda sebagai bangsa yang paling lama menguasai bangsa Indonesia sudah melakukan banyak kebijakan-kebijakan yang sangat merugikan rakyat Indonesia.

Sikap kolonial Belanda telah menumbuhkan benih-benih ketidakpuasan bangsa Indonesia sehingga para pemuka agama menghimpun kekuatan melalui dunia pesantren di antaranya adalah Nahdlatul Ulama (NU). Ditambah adanya beberapa program kristenisasi yang digalakkan oleh penjajah Belanda. Pada masa penjajahan Jepang menguasai Indonesia, arena perjuangan NU justru semakin melebarkan sayapnya. Sikap anti penjajah yang memang sudah pembawaannya, menyebabkan antisipasi terhadap perkembangan keadaan yang menyangkut keselamatan negara semakin ditingkatkan, lebih-lebih lagi ketika kehadiran tentara sekutu dan NICA (Belanda) mendarat di Indonesia dan dimana-mana melakukan teror untuk merobohkan negara Republik Indonesia yang masih sangat mudah pada waktu itu.

Kondisi yang sangat genting seperti ini menjadikan NU di bawah kepemimpinan $\mathrm{KH}$. Hasyim Asy'ari (yang merasa mempunyai andil dalam proses-proses perumusan kemerdekaannya) terdorong untuk mengeluarkan sebuah fatwa terkenal dengan nama "Resolusi Jihad" pada tanggal 22 Oktober 1945.

Sebuah kebulatan tekad yang isinya mewajibkan kepada seluruh umat Islam baik pria maupun wanita mengangkat senjata melawan kolonialisme dan imperialisme yang mengancam keselamatan negara Republik Indonesia. Peran NU dan keterlibatannya yang besar hampir seluruh warga NU untuk menjalankan jihad mengusir penjajah ini, pada gilirannya bisa mendorong kehendak kuat bagi negara dan NU untuk menuntut peranannya yang lebih besar dalam perjuangan selanjutnya yang tentunya berlandaskan pada semangat nilai-nilai Resolusi Jihad dengan bentuk aktualisasi yang lain.

Arti penting lain pembentukan NU sebagai sebuah organisasi adalah berkaitan dengan wawasan kebangsaan (nasionalisme) yang selalu dijadikan sebagai salah satu dasar perjuangannya selama ini. Wawasan kebangsaan yang dimiliki oleh NU tersebut dapat dilihat pada setiap langkah dan kebijakan NU sejak dulu hingga sekarang yang selalu mengutamakan kepentingan bangsa dan negara.

Perjuangan Nahdlatul Ulama' ini berkobar terus mulai sejak penjajahan Belanda menyerbu Indonesia sampai penjajahan Jepang. Oleh karenanya tujuan Nahdlatul Ulama' 
membentuk sebuah perkumpulan adalah untuk membentuk organisasi perjuangan yang senantiasa menentang segala bentuk penjajahan untuk merebut kemerdekaan dan sekaligus menjaga kesatuan negara Republik Indonesia dalam wadah NKRI.

Dari latar belakang ini, maka peneliti ingin membahas tentang kontribusi Nahdlatul Ulama' dalam perjuangan kemerdekaan negara Republik Indonesia dan pandangan Nahdlatul Ulama' dalam mempertahankan kedaulatan RI dalam bingkai negara kesatuan Republik Indonesia.

Menurut Thomas Stamford Raffles, peran kelompok ulama yang strategis ini bukanlah hasil dari voting (pemilihan suara) atau dari pengaruh karisma raja, tetapi lahir dari perkembangan Islam itu sendiri yang memandang ulama sebagai kelompok intelektual Islam, dan tampaknya telah menjadi watak dasar bangsa Indonesia yang selalu mengangkat kalangan berilmu sebagai pemimpinnya. 13

Kehadiran ulama dalam masyarakat telah diterima sebagai pelopor pembaharuan, dan pengaruh ulama pun semakin mendalam setelah berhasil membina pesantren. Eksistensi ulama jangan dilihat hanya sekedar sebagai pembina pesantren saja, akan tetapi peranannya dalam sejarah perjuangan bangsa cukup militan. Sekalipun banyak penulis sejarah yang menyingkirkan peran para ulama dalam karyanya, namun Raffles menuliskan betapa besar peranan ulama dalam menunjang para Sultan melawan Belanda. ${ }^{14}$

Menurutnya, "ulama merupakan kelompok intelektual yang sangat kuat dan membahayakan di tangan penguasa-penguasa pribumi dalam rangka melawan penjajahan Belanda dan kelompok ulama senantiasa aktif menggerakkan perjuangan dan memberikan spirit untuk melakukan pemberontakan pada penjajah Belanda”. ${ }^{15}$

Kelanjutan dari pengaruh ulama yang demikian luas tersebut tidak hanya terbatas di bidang politik dan militer saja, melainkan meluas juga terhadap ekonomi yang telah meninggalkan bekas-bekasnya baik berupa aktivitas perdagangan, tukar menukar barang ekonomi, kegiatan perniagaan lain yang produktivitasnya untuk menopang perekonomian keluarga dan perjuangan agama. ${ }^{16}$

13 Amin Farih, "Nahdlatul Ulama (NU) dan Kontribusinya dalam Memperjuangkan Kemerdekaan dan Mempertahankan Negara Kesatuan Republik Indonesia (NKRI)", Walisongo, Volume 24, Nomor 2, November 2016, hlm. 263-264.

14 Thomas Stamford Raffles menyatakan: "and they become the most dangerous instrument in the hands of the native authorities opposed to the Dutch interest" ........ The Mahometan priests have almosth invariably been found most active in every case of insurrection. Lihat: Thomas Stamford Raffles, The History of Jawa, Jakarta: Narasi Press, 1976, hlm. 77, dalam Amin Farih, Ibid., hlm. 264.

15 Ibid.

16 Ibid. 
Pasar tidak hanya merupakan kegiatan jual beli barang dagangan, tetapi juga dijadikan arena dakwah, sehingga kegiatan pasar sangat dipengaruhi oleh hari-hari besar Islam. Jadi, Islam sebagai agama yang disebarkan di Indonesia oleh para ulama, memiliki peran yang positif dalam menunjang kegiatan-kegiatan sosial, politik dan kegiatan perekonomian dan perdagangan. 17

Kalau kita telisik kembali, jelaslah bahwa kepentingan Belanda di Indonesia mendapatkan rintangan dari ulama, terutama di bidang perdagangan dan kebijakan politik kolonial. Belanda melihat kegiatan umat Islam yang mempunyai dwi fungsi sebagai dai dan pedagang, mengakibatkan usaha perdagangan Belanda menghadapi ancaman dari umat Islam, maka tidak mengherankan kalau Islam dijadikan sebagai senjata politik dalam melawan para Belanda. Para ulama dan para kiai mempunyai pengaruh yang sangat besar, terlebih karena sifat pendidikan agama di pesantren, pondok yang mengarah pada orientasi vertikal kalangan santri kepada para guru, yang menyebabkan pengaruh kewibawaan para ulama dan kiai sangat besar. Karena itulah, dalam menjangkau perspektif pembangunan politik di Indonesia dalam arti yang seluas-luasnya, para ulama sangat berperan penting dalam kehidupan bermasyarakat, berbangsa dan bernegara. Peran ulama dalam perjuangan kemerdekaan negara Republik Indonesia tidak hanya sebagai pengobar semangat santri dan masyarakatnya, akan tetapi juga bertujuan mempengaruhi pemerintah agar segera menentukan sikap melawan kekuatan asing yang ingin menggagalkan kemerdekaan negara Republik Indonesia.18

Jauh sebelumnya, yaitu masa pendudukan Jepang, kaum ulama dan santrinya sudah bersiap-siap menyusun kekuatan. Laskar Hizbullah, dan Sabilillah didirikan menjelang akhir pemerintahan Jepang, dan mendapat latihan kemiliteran di Cibarusah, sebuah desa di Kabupaten Bekasi, Jawa barat. Laskar Hizbullah berada di bawah komando spiritual, yaitu KH. Hasyim Asyari dan secara militer dipimpin oleh KH. Zaenul Arifin. Sementara, laskar Sabilillah dipimpin oleh KH. Masykur. Peran kiai dan santri dalam perang kemerdekaan ternyata tidak hanya dalam laskar Ḥizbullah dan Sabilillah saja, tetapi banyak di antara mereka yang menjadi anggota tentara PETA (Pembela Tanah Air).

Resolusi Jihad tidak terlepas dari peran Hizbullah, peran mereka nyata terlihat setelah berkumpulnya para kiai se-Jawa dan Madura di kantor Ansor Nahdlatul Ulama pada tanggal 21

17 Thomas Stamford Raffles, The History of Jawa, Jakarta: Narasi Press, 1976, hlm. 76, dalam Amin Farih, Ibid,

18 Salman Akif Faylasuf, "Peran Ulama NU dalam Mengusir Penjajah", The Columnist, https://thecolumnist.id/artikel/peran-ulama-nu-dalam-mengusir-penjajah--1623, diakses pada tanggal 12 September 2021. 
Oktober 1945. Setelah rapat darurat sehari semalam, maka pada 22 Oktober dideklarasikan seruan jihad fi sabilillah yang belakangan dikenal dengan istilah Resolusi Jihad. ${ }^{19}$ Adapun resolusi yang diputuskan dalam rapat para konsul Nahdlatul Ulama' se-Jawa itu berbunyi:

1) Kemerdekaan Indonesia yang diproklamirkan pada 17 Agustus 1945 wajib dipertahankan.

2) Republik Indonesia (RI) sebagai satu-satunya pemerintahan yang sah, wajib dibela dan diselamatkan.

3) Musuh negara Republik Indonesia, terutama Belanda yang datang dengan membonceng tentara Sekutu (Inggris) dalam masalah tawanan perang bangsa Jepang tentulah akan menggunakan kesempatan politik dan militer untuk kembali menjajah Indonesia.

4) Umat Islam, terutama NU wajib mengangkat senjata melawan Belanda dan kawankawannya yang hendak kembali menjajah Indonesia.

5) Kewajiban tersebut adalah jihad yang menjadi kewajiban tiap-tiap Muslim yang berada pada jarak radius $94 \mathrm{~km}$ (jarak dimana umat Islam diperkenankan salat jamā' dan qașr). ${ }^{20}$

Resolusi jihad tersebut akhirnya mampu membangkitkan semangat arek- arek Surabaya untuk bertempur habis-habisan melawan penjajah. Dengan semangat takbir yang dipekikkan oleh Bung Tomo, maka terjadilah perang rakyat yang heroik pada 10 November 1945 di Surabaya. Dari sejarah ini, warga NU dan para elitenya, tidak menjadi alergi ketika akhir-akhir ini ada upaya untuk mengebiri dan mengaburkan makna jihad. Resolusi Jihad yang diserukan KH. Hasyim Asy'ari, sebaiknya diingat kembali untuk memberikan motivasi kepada generasi muda dalam mempertahankan kemerdekaan dan kedaulatan bangsa dan negara.

\section{Nahdlatul Ulama Sebagai Organisasi Yang Pluralisme}

Berakhirnya Perang Dingin dan berkembangnya fenomena globalisasi, mendorong per- ubahan terhadap konsentrasi keamanan negara. Secara tradisional, keamanan didefinisikan dari perspektif geo-politik, dengan menekankan pada aspek-aspek seperti strategi penangkalan (detterence), perimbangan kekuatan (power balancing), dan strategi militer.

19 Ibid.

20 M. Mas'ud Adnan, Resolusi Jihad dalam Peristiwa 10 November, Surabaya: Jawa Pos, 1999, hlm. 87. Lihat juga dalam: Lathiful Khuluq, Fajar Kebangunan Ulama: Biografi Kiyai Hasyim Asyari, Yogyakarta: LkiS, 2000, hlm. 29, dalam Amin Farih, Op. cit., hlm. 268. 
Dengan segala dampak menguntungkan dan merugikan dari globalisasi, yang terproses dalam dimensi yang beragam pula, menuntut negara untuk lebih memperhatikan keamanan dari perspektif non-konvensional. Dimana aspek-aspek ideologi, ekonomi, budaya, sosialpolitik, teknologi, militer, pertahanan negara, dan seterusnya, sebagai dimensi yang mampu menciptakan ancaman. 21

Ancaman yang harus kita tanggulangi dalam rangka mempertahankan keutuhan Negara Kesatuan Republik Indonesia adalah setiap upaya dan kegiatan, baik dari dalam negeri maupun luar negeri yang dinilai mengancam atau membahayakan kedaulatan negara, keutuhan wilayah negara, dan keselamatan segenap bangsa. Di tengah era globalisasi yang melahirkan ideologi kapitalisme, kedaulatan wilayah negara Republik Indonesia menghadapi tantangan dari upayaupaya pencaplokan pulau-pulau terpencil oleh negara lain. Hal ini dikarenakan wilayah Indonesia baik darat maupun perairan memiliki kekayaan alam yang melimpah sehingga menjadi sasaran negara lain.

Dampak globalisasi dan euforia demokrasi yang kebablasan ini telah membuka seluasluasnya pintu kebebasan, bahkan kebebasan yang menjurus pada tindakan makar terhadap negara pun leluasa bergerak. Namun bagi NU, NKRI (Negara Kesatuan Republik Indonesia) merupakan upaya final dari perjuangan seluruh penduduk Indonesia. Negara Kesatuan Republik Indonesia adalah negara yang sah menurut hukum Islam, yang menjadi wadah berkiprah melaksanakan dakwah yang akomodatif dan selektif, serta bertakwa sesempurna mungkin, tidak usah mencari atau membuat negara yang baru.

Bahkan merujuk Resolusi Jihad 22 Oktober 1945, mempertahankan dan menegakkan NKRI (Negara Kesatuan Republik Indonesia) menurut hukum agama Islam adalah wajib, termasuk sebagai satu kewajiban bagi tiap-tiap muslim, dan jihad fi sabilillah. Karena itu, NU mempunyai tanggung jawab terhadap kehidupan kebangsaan dan kenegaraan, baik dahulu, sekarang, maupun masa mendatang.

\section{KESIMPULAN}

Keberhasilan Nahdlatul Ulama' memberikan penyelesaian paradigmatis relasi agama dan negara ini mengindikasikan adanya pergeseran paradigma di kalangan Nahdlatul Ulama' sendiri dalam memandang kenyataan Bangsa dan Negara. Baik pada aspek siyāsah, maupun

21 I Gede Sukahatya, “Analisis Komponen Pendidikan Militer Indonesia pada Era Globalisasi dengan Metode Importance And Performance Analysis (Studi Akademi Militer Magelang)", Universitas Indonesia Library, http://lib.ui.ac.id/detail?id=20410194\&lokasi=lokal, diakses pada tanggal 12 September 2021. 
aspek hukum dan peradaban, transformasi pemikiran di kalangan Nahdlatul Ulama' terus menggelinding. Nahdlatul Ulama' pimpinan Hadhratus Syaikh KH. Hasyim Asy'ari sangat menjunjung tinggi nilai-nilai kebangsaan, nasionalisme yang berdasar atas syariat Islam ala $A h l$ al-Sunnah wal-Jamā'ah. Bukti sikap nasionalis yang tunjukkan Nahdlatul Ulama' adalah peristiwa dimana sebelum negara Republik Indonesia merdeka, para pemuda di berbagai daerah mendirikan organisasi bersifat kedaerahan, seperti Jong Cilebes, Pemuda Betawi, Jong Java, Jong Ambon, Jong Sumatera, dan sebagainya, akan tetapi Kyai-Kyai NU justru mendirikan organisasi pemuda bersifat nasionalis.

\section{Daftar Pustaka}

\section{Buku}

Adnan, M. Mas'ud, Resolusi Jihad dalam Peristiwa 10 November, Surabaya, Jawa Pos, 1999.

Khuluq, Lathiful, Fajar Kebangunan Ulama: Biografi Kiyai Hasyim Asyari, Yogyakarta: LkiS, 2000. Raffles, Thomas Stamford, The History of Jawa, Jakarta: Narasi Press, 1976.

Redaksi Sinar Grafika, Undang-Undang 1945 Hasil Amandemen dan Proses Amandemen UndangUndang 1945 Secara Lengkap, cetakan keenam, Jakarta: Sinar Grafika, 2009.

Ruslan, Achmad, Teori dan panduan Praktik Pembentukan Peraturan Perundang-undangan di Indonesia, Yogyakarta: Rangkang Education dan Republik Institute, 2013.

Shobron, Sudarno, Muhammadiyah dan NU Dalam Pentas Politik Nasional. Surakarta: Muhammadiyah University Press, 2009.

Soekanto, Soerjono, Pengantar Penelitian Hukum, Jakarta: UI Press, 1981.

Soemitro. R.H, Metodologi Penelitian Hukum, Jakarta: Ghalia Indonesia, 1983.

Zahro, Ahmad, Tradisi Intelektual NU Lajnah Bahtsul Mas"ail 1926-1999, Yogyakarta: LKIS Yogyakarta 2004.

Aswaja dan Ke-NU-an, Yogyakarta: Ma'arif NU DIY, 2004.

\section{Jurnal dan Makalah}

Farih, Amin, “Nahdlatul Ulama (NU) dan Kontribusinya dalam Memperjuangkan Kemerdekaan dan Mempertahankan Negara Kesatuan Republik Indonesia (NKRI)", Walisongo, Volume 24, Nomor 2, November 2016.

Hamdani, Fikri, “Wacana Hadis dalam Manhaj Nahdlatul Ulama”, Rausyan Fikr, Vol. 13 No.1 Juni 2017. 


\section{Situs Web}

"Dasar-Dasar Paham Keagamaan Nahdlatul Ulama", Laduni.id, https://www.laduni.id/post/read/61456/dasar-dasar-paham-keagamaan-nahdlatululama, diakses pada tanggal 12 September 2021.

Faylasuf, Salman Akif, "Peran Ulama NU dalam Mengusir Penjajah", The Columnist, https://thecolumnist.id/artikel/peran-ulama-nu-dalam-mengusir-penjajah--1623, diakses pada tanggal 12 September 2021.

Sukahatya, I Gede, “Analisis Komponen Pendidikan Militer Indonesia pada Era Globalisasi dengan Metode Importance And Performance Analysis (Studi Akademi Militer Magelang)", Universitas Indonesia Library, http://lib.ui.ac.id/detail?id=20410194\&lokasi=lokal, diakses pada tanggal 12 September 2021. 